\title{
New or Little Reported Sask. Plants
}

\section{By John Howard Hudson, Regina}

The dry weather this summer has made botanical collecting unrewarding. However, we were able to pick up a few plant curiosities this spring, such as:

Astragalus purshii Douglas (Pursh's Milk Vetch). Collected by Dr. G. F. Ledingham and myself May 18 on dry short grass prairie south-east of Climax, on N.E. 1/4 1-2-18 W. 3rd. Also seen by us on the same day on Boundary Plateau N.E. $1 / 4$ 14-1-23 W. 3rd and the next day at the east end of Old-Man-onhis-Back Plateau N.W. 1/4 33-2-24 W. 3rd. This plant looks much like A. lotiflorus except that the purplekeeled creamy flowers are about 2 $\mathrm{cm}$. long and always stalked, and that the podis are densely covered with long silky hairs. It has a wide range in the High Plains and Great Basin areas of the U.S., apparently just crossing the border into Saskatchewan.

Antennaria dimorpha (Nutt) T. \& G. Collected by G. F. Ledingham and myself May 18 N.E. 1/4 1-2-18 W. 3rd (south-east of Climax) and on May 19 on S.W. 1/4 3-3-24 (east end OldMan-on-his-Back Plateau). This species of the Antennaria or Pussypaws genus is distinctly different from the usual run of Antennarias. It does not spread by runners, but grows in patches about 5-6 cm. diameter from a woody crown. The pistillate (female) plants are totally stemless, bearing 12-18 mm. long and $4 \mathrm{~mm}$. in diam. scattered singly on the plant. The staminate heads are also borne singly, but on apologies for stems about $1 \mathrm{~cm}$. high. These staminate heads are of more orthodox Antennaria form, hemispheric and about $6 \mathrm{~mm}$. across. Since the leaves are grey-green, narrowly oblanceolate, and about $1 \mathrm{~cm}$. long, the pistillate plant looks remarkably like a Tcwnsendia. Rydberg gives the range as "Mont.-Neb.-Colo.-Nev.B.C."

Astragalus Kentrophyta A. Gray. Since this plant is reported in Budd's standard flora of our area, I need only remark that G. F. Ledingham and I found this plant on May 17 on S.E. 1/4 13-15-17 W. 3rd, on a windswept gravel flat among sand dunes north of Webb. I took flowering specimens here on June 5 .

Draba micrantha Nutt. Found this in a gravel pit June 11, N.W. $1 / 4$ 185-12 W. 2nd, south-east of Goodwater. This small mustard looks something like the related Draba nemerosa, Yellow Whitlow - grass, which is common. The differences are: few or no stem-leaves (leaves mostly basal); stalks bearing pods diverging from about the same place at the top of the stem; pods about twice the size, 10-12 $\mathrm{mm}$. long, 4 $\mathrm{mm}$. wide. The plant is widespread through the Middle West of the U.S.A.

\section{Lichen, A Plant Which Grows Almost Everywhere}

\section{By Joyce Dew, Saskatchewan Museum of Natural History}

Lichens are very common plants. They can grow where no other plant can grow and are found living in more different places than any other plant. They can live on bare rocks, in the cold Arctic or on mountain tops, in tropical jungles and in your own back yard. They are a plant which you can find growing at any time of the year unless the ground is heavily covered with snow. The only place where you are not likely to find them is in and near cities.
You have certainly seen lichens, but perhaps you were not aware of what they were.

Lichens are great pioneers and help to make soil from rocks. When the weather is dry they dry up and shrink, then when it rains they start to grow again. Since they cling tightly to the rock, this expanding and shrinking breaks off rock particles. Lichens also secrete an acid which helps dissolve the rock. The rock particles along with tiny bits 


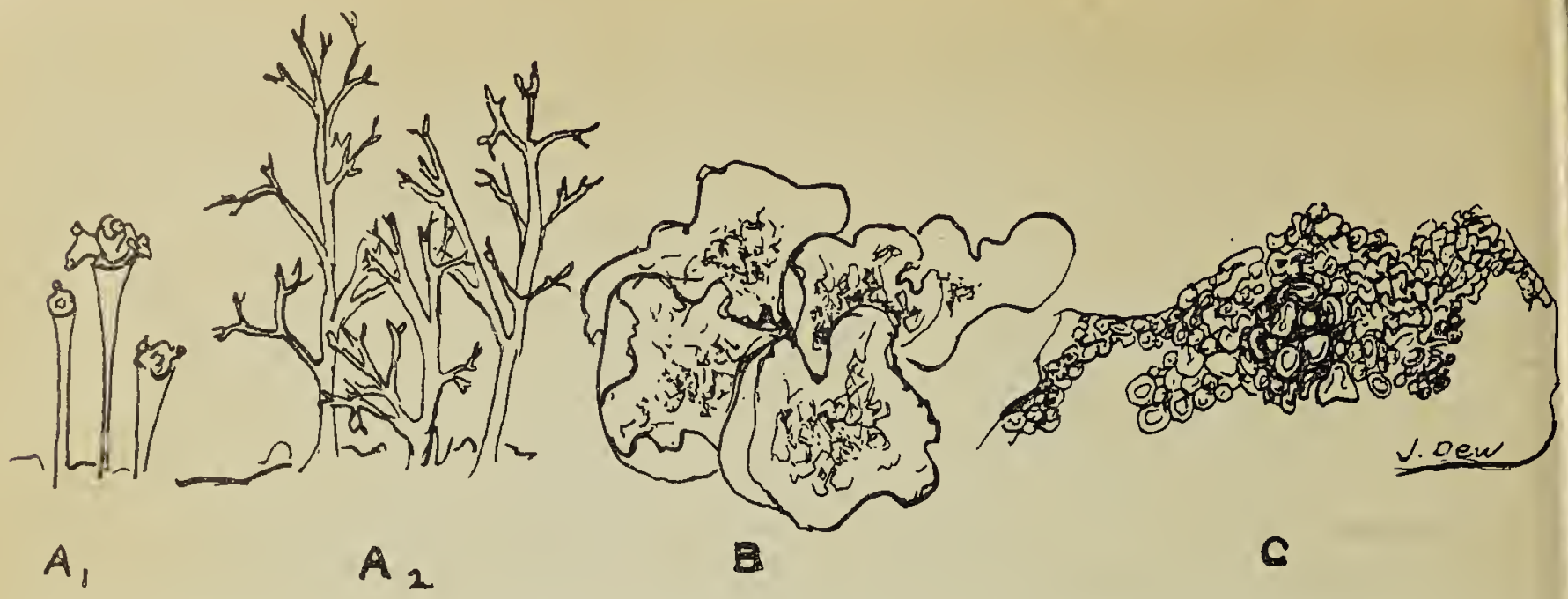

of dead lichen form soil. Soon other plants are able to grow where once only lichens could grow.

The crustose lichens are one of the most common and come in various colours, among them black, green, yellow and rust. These, as their name suggests, are crusty scalelike plants. They are found clinging tightly to rocks or dry wood.

To find crustose lichen look for rocks which have been lying undisturbed for some time. Rocks from gravel pits, or rocks freshly turned out of the soil, are not likely to have lichens growing upon them. Crustose lichen can be found in any part of the province. The one illustrated here (C) was found growing on a rock along the shore at Last Mountain Lake. To collect this lichen, you will need a hammer and chisel to chip it loose from the rocks, unless you are prepared to carry the whole rock with you.

Some lichens grow in small erect clumps and branch like miniature trees (A). These are fructose lichens. Two of the fructose lichens commonly found in wooded areas in cen-

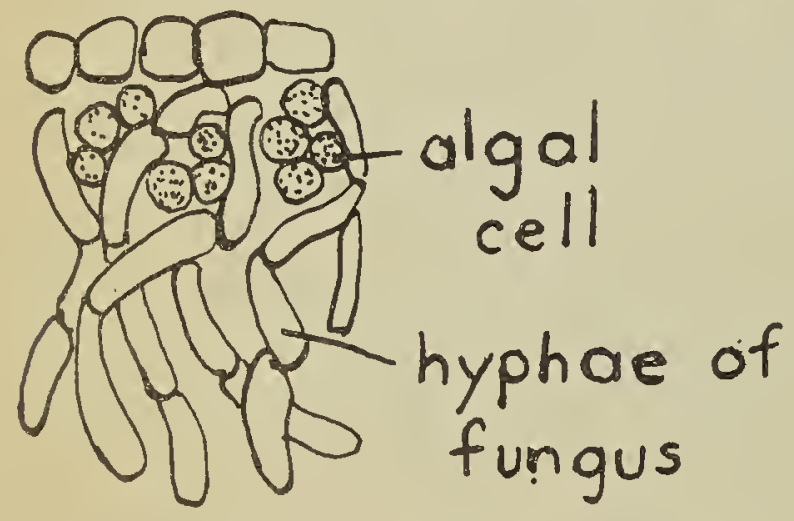

Microscopic cross-section af a lichen. tral and northern Saskatchewan are illustrated here. They are both pale green in colour and grow to be about an inch in height. Reindeer Moss (A2), as one of those lichens is commonly called, is the regular diet of caribou and musk-ox. Those of you visiting the Saskatchewan Museum of Natural History can see Reindeer Moss in the Barren Ground Caribou display.

A third type of lichen is foliose lichen (B). Foliose lichens are leaflike in appearance. One of the commonest, illustrated here, is apple green to brownish above, white below when fresh, with dark veins. Foliose lichen and fructose lichen in combination with mosses and small woodland plants can be easily grown. in terrariums.*

There are over 16,000 species of lichens, yet all of them have one thing in common. Each lichen consists of two plants growing together: a fungus and an alga. One fungus everyone is acquainted with is the mushroom; algae are common as green pond scum.

Since the fungi and the algae which make up the lichen elach benefit from the relationship, they are said to be living in symbiosis. The fungus cannot manufacture its own food but it provides protection for the algae. The algal cells in the lichen are round cells. The hyphae (threads) of the fungus wrap around the algal cells and take some of the food which the algal cells manufacture.

* Send to the Saskatchewan Museum of Natural History for a folder on "How to Set Up a Terrarium".

\section{FIELD CHECK-LIST OF SASK. BIRDS}

The revised field check-list of Sask. birds is available free from the Saskatchewan Museum of Natural History, Regina. 